\title{
Fossil landscapes and youthful seismogenic sources in the central Apennines: excerpts from the 24 August 2016, Amatrice earthquake and seismic hazard implications
}

\author{
GIANLUCA VALENSISE ${ }^{*}$, PAOLA VANNOLI ${ }^{1}$, ROBERTOBASILI ${ }^{1}$, LORENZO BONINI ${ }^{2,1}$, \\ PIERFRANCESCOBURRATO', MICHELE MATTEO COSIMO CARAFA ${ }^{3}$, \\ UMBERTO FRACASSI ${ }^{1}$, VANJA KASTELIC ${ }^{3}$, FRANCESCO EMANUELE MAESANO', \\ MARA MONICA TIBERTI ${ }^{1}$, GABRIELE TARABUSI ${ }^{4}$ \\ ${ }^{1}$ Istituto Nazionale di Geofisica e Vulcanologia, Sezione Roma 1, Roma, Italy \\ ${ }^{2}$ Dipartimento di Matematica e Geoscienze, Università di Trieste, Italy \\ ${ }^{3}$ Istituto Nazionale di Geofisica e Vulcanologia, Sezione Roma 1, L'Aquila, Italy \\ ${ }^{4}$ Istituto Nazionale di Geofisica e Vulcanologia, Sezione Roma 1, Bologna, Italy \\ *gianluca.valensise@ingv.it
}

\begin{abstract}
We show and discuss the similarities among the 2016 Amatrice (Mw 6.0), 1997 Colfiorito-Sellano (Mw 6.0-5.6) and 2009 L'Aquila (Mw 6.3) earthquakes. They all occurred along the crest of the central Apennines and were caused by shallow dipping faults between 3 and $10 \mathrm{~km}$ depth, as shown by their characteristic InSAR signature.

We contend that these earthquakes delineate a seismogenic style that is characteristic of this portion of the central Apennines, where the upward propagation of seismogenic faults is hindered by the presence of preexisting regional thrusts. This leads to an effective decoupling between the deeper seismogenic portion of the upper crust and its uppermost $3 \mathrm{~km}$.

The decoupling implies that active faults mapped at the surface do not connect with the seismogenic sources, and that their evolution may be controlled by passive readjustments to coseismic strains or even by purely gravitational motions. Seismic hazard analyses and estimates based on such faults should hence be considered with great caution as they may be all but representative of the true seismogenic potential.
\end{abstract}

\section{INTRODUCTION}

The 24 August 2016, Amatrice earthquake $\left(M_{w} 6.0\right)$, which devastated a portion of the Central Apennines causing nearly 300 victims and substantial property damage, occurred in an especially well monitored region. Hence it has taken merely two days to realize that the Amatrice earthquake, although sharing the general characteristics of other Apennines extensional events, exhibits peculiarities that took many earthquake geologists by surprise. Scientists were once again confronted with a complex rupture, too deep and too shallow-dipping to connect with the active faults known in the region, and breaking across what many considered a major regional tectonic boundary (the Monti Sibillini Thrust).

The Amatrice earthquake is the last of three disastrous, similarly-sized earthquake sequences, all caused by normal faulting along planes dipping $40^{\circ}-50^{\circ}$ to the southwest. The 2016 sequence follows the 6 April 2009 L'Aquila earthquake $\left(M_{w} 6.3\right)$, 
with its strong 9 April aftershock in the Campotosto-Monti della Laga area $\left(\mathrm{M}_{\mathrm{w}} 5.4\right)$, and the 26 September and 14 October, Colfiorito-Sellano earthquakes $\left(\mathrm{M}_{\mathrm{w}} 5.7,6.0\right.$ and 5.6), respectively located to the southeast and to the northwest of Amatrice along the Apennines crest (Fig. 1). These earthquakes delineated a tectonic style that is largely at odds with the views on the active tectonics of the central Apennines that dominated the scientific debate over the past thirty years (see discussion in Vannoli et al. [2012]).

After summarizing the established facts concerning the epicentral region (\$2) we discuss the constraints arising from the tectonic and landscape evolution of the central Apennines (\$3) and from InSAR evidence for coseismic strains in recent extensional earthquakes (\$4). Finally we focus on the implications of our findings for an improved assessment of the regional seismic hazard (\$5).

The three sequences share the availability (a) of numerous and reliable earthquake data collected by the permanent INGV network and by temporary networks, and (b) of good quality InSAR data. The latter in particular proved fundamental for understanding the details of the source processes and unraveling the puzzle of their associated surface coseismic deformation, represented by limited or ambiguous surface breaks for all three earthquakes.

InSAR observations (Fig. 2) are by far the best tool available for modern Earthquake Geology, as they:

- carry a multi-wavelength signal that can be interpreted, with appropriate filtering, to investigate the properties of the main seismogenic source separately from the associated secondary and gravity-driven effects;

- provide a framework for interpreting the geology and landscape evolution resulting from repeated faulting;
- are sensitive to the fault patches that experienced the largest slip and insensitive to finer details of the coseismic ruptures.

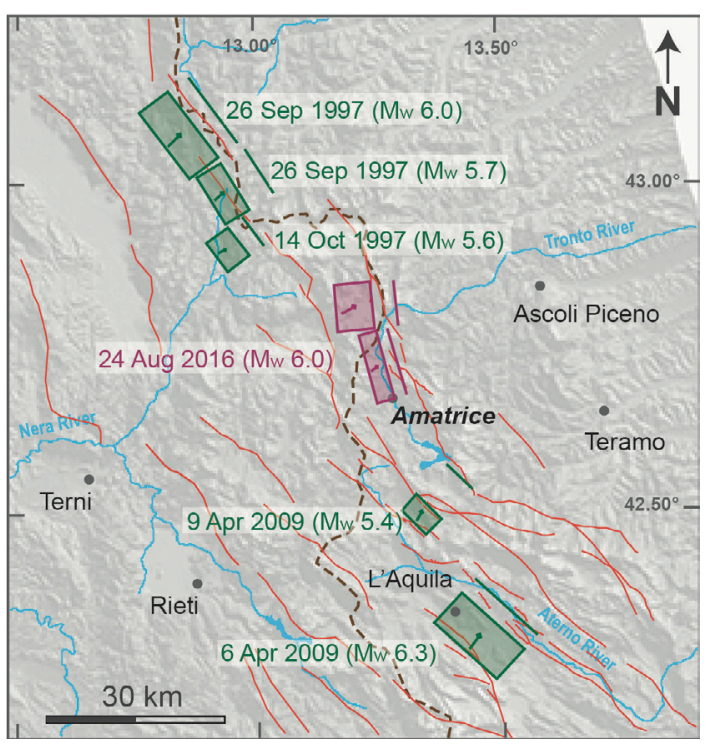

Figure 1. Geographic setting and seismogenic sources discussed in text. Active faults from various sources are shown in red. Sources in green are from the DISS database [DISS Working Group 2015]. The two subsources proposed for the Amatrice earthquake, in purple, are from Gruppo di Lavoro IREA \& INGV [2016]. A dashed line shows the regional watershed.

\section{PREVIOUS AND ESTABLISHED KNOWLEDGE}

Similarly to the L'Aquila and Colfiorito regions, the area that spawned the Amatrice earthquake has long been known as earthquake-prone. Yet, the understanding of the exact location and characteristics of its seismogenic sources has always been limited. Common characteristics of the 1997, 2009 and 2016 sequences are (see Fig. 2 and Table 1):

- faulting occurred between 3 and $10 \mathrm{~km}$ depth on southwest-dipping faults striking parallel to the local trend of the Apennines;

- little or no slip was observed above $3 \mathrm{~km}$ depth, either by seismological methods or by inversion of GPS and InSAR data; 

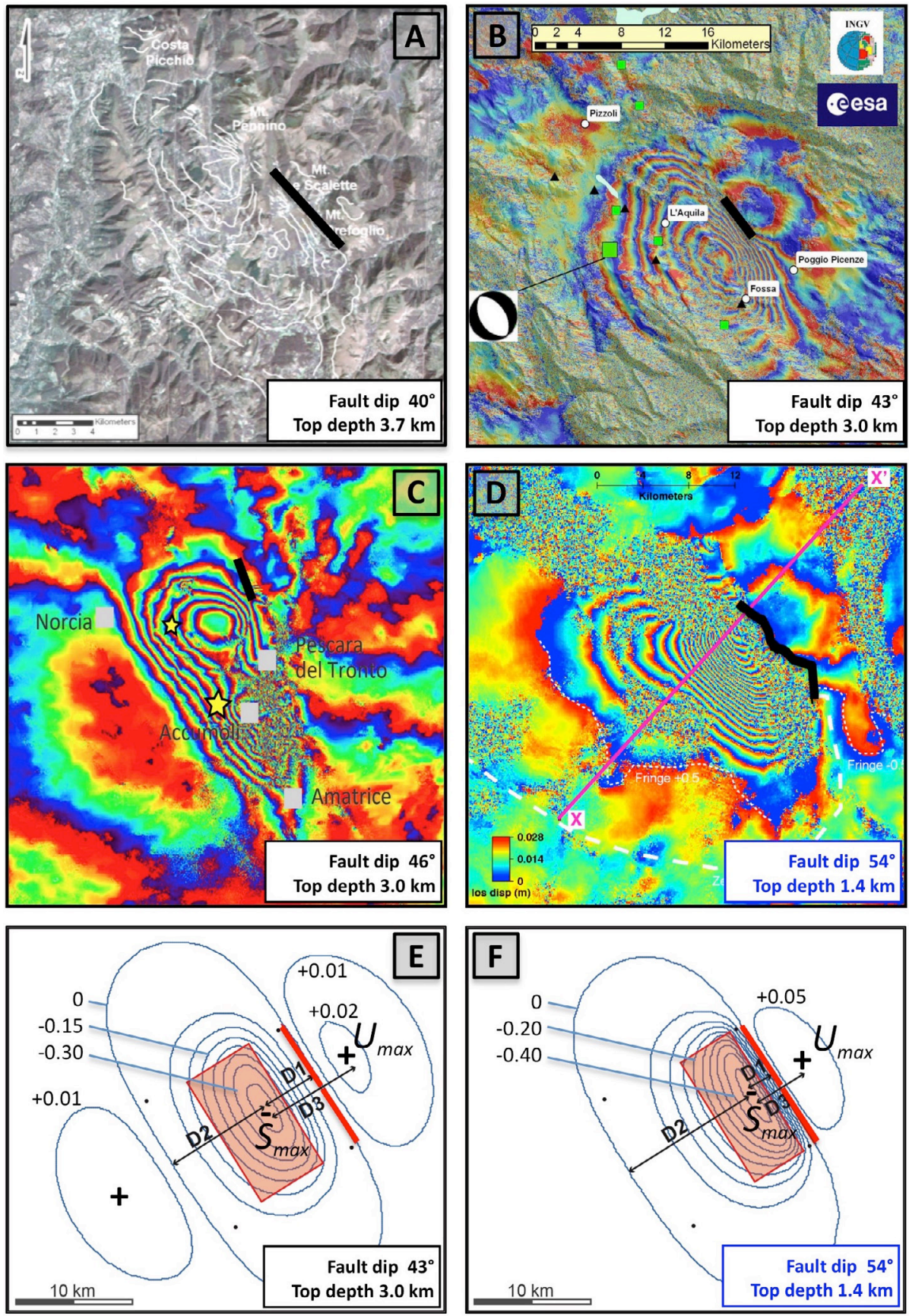

Figure 2. Panels A-D: comparison of InSAR models. (A) 1997 Colfiorito earthquake [Moro et al. 2007]; (B) 2009 L'Aquila earthquake [ESA, 2009]; (C) 2016 Amatrice earthquake, solution obtained from Sentinel-1 data [Gruppo di Lavoro IREA \& INGV 2016]; (D) 1995 Dinar, Turkey earthquake [Douglas and Funning 2016]. The observed or presumed - depending on cases - surface expression of the fault is shown by a thick black line. Panels E-F: comparison of the "coseismic signature" obtained for two distinct model faults, showing the extent of coseismic uplift and subsidence per unit slip: (E) is an average of the models obtained for the 1997, 2009 and 2016 earthquakes, (F) reproduces the 1995 Dinar earthquake. A thick red line shows the surface projection of the fault plane. See also Tables 1 and 2. 
ANNALS OF GEOPHYSICS, 59, Fast Track 5, 2016; DOI: 10.4401/ag-7215

\begin{tabular}{|c|c|c|c|c|c|c|c|c|c|c|}
\hline $\begin{array}{c}\text { Colfiorito I } \\
\text { 1997, } 26 \text { Sep, 00:33 }\end{array}$ & 1 & 148 & 40 & 277 & 9.0 & 6.0 & $4.0 / 7.8$ & 0.38 & 5.7 & None (a) \\
\hline $\begin{array}{l}\text { Colfiorito II } \\
\text { 1997, } 26 \text { Sep, 09:40 }\end{array}$ & 1 & 143 & 40 & 275 & 14.0 & 8.0 & $3.4 / 8.5$ & 0.33 & 6.0 & None (a) \\
\hline $\begin{array}{l}\text { Sellano } \\
\text { 1997, } 14 \text { Oct, 15:23 }\end{array}$ & 1 & 144 & 40 & 260 & 6.0 & 6.0 & $2.5 / 6.5$ & 0.28 & 5.6 & $\begin{array}{l}\text { Minor breaks } \\
\text { (b) }\end{array}$ \\
\hline $\begin{array}{c}\text { Campotosto } \\
\text { 2009, } 9 \text { Apr, 00:52 }\end{array}$ & 3 & 135 & 45 & 275 & 5.9 & 5.2 & $7.3 / 11.0$ & 0.10 & 5.4 & None \\
\hline $\begin{array}{c}\text { Amatrice } \\
\text { 2016, } 24 \text { Aug, 01:35 }\end{array}$ & 4 & $165-175$ & $39-51$ & $295-290$ & $\begin{array}{c}8.0 \\
12.0\end{array}$ & $\begin{array}{l}8.0 \\
5.0\end{array}$ & $\begin{array}{l}3.0 / 8.0 \\
2.5 / 6.4\end{array}$ & 0.70 & 6.0 & $\begin{array}{c}\text { Up to } 20 \mathrm{~cm} \\
\text { along Vettore } \\
\text { Fault }(\mathrm{d})\end{array}$ \\
\hline
\end{tabular}

Table 1. Fault parameters for the 1997, 2009 and 2016 central Apennines earthquakes, and for the 1995 Dinar, southern Turkey earthquake: (1) DISS Working Group [2015]; (2) Vannoli et al. [2012]; (3) this work; (4) Gruppo di Lavoro IREA \& INGV [2016]; (5) Wright et al. [1999]. Surface breaks reports: (a) Basili et al. [1998]; (b) Cinti et al. [2000]; (c) Vannoli et al. [2012]; (d) EMERGEO Working Group [2016]; (e) Wright et al. [1999]. Notice that the Amatrice fault was modeled using two distinct planes (parameters from Gruppo di Lavoro IREA E INGV [2016]).

- seismological, InSAR and GPS observations combined indicate that the dip of the seismogenic fault is in the range $39^{\circ}-51^{\circ}$, much lower than the dip commonly reported for central Apennines active faults [e.g. Vannoli et al., 2012] but coherent with a recent elaboration on the fault dip distribution of global normal faulting earthquakes [Basili and Tiberti, 2016];

- as a result of the limited width of the rupture plane and of coseismic slip $(<10 \mathrm{~km}$ and $<1 \mathrm{~m}$, respectively), the three earthquakes also exhibit a relatively small magnitude. Similarly to thrust faults, however, the shallow dip of the fault may allow for substantially larger ruptures;

- in all cases the rupture appeared to be vertically confined by the interference with thrust planes dating to the build-up of the Apennines fold-and-thrust belt (Fig. 3).

\section{RELATIONS WITH SURFACE STRUCTURES: LANDSCAPE FEATURES}

Over the past two decades various investigators have pointed out that the extensional tectonic regime responsible for the normal faulting earthquakes that occur along the crest of the Apennines is relatively young. For example, the age of inception of one of the main and oldest extensional structures in the central and northern Apennines, the Etrurian Fault System, dates back to the Late Pliocene-Early Pleistocene (see Pucci et al. [2014], and references therein). A straightforward implication of this finding is that, given the current rates of extension in the Apennines, the amount of topography that has been created at any point after the inception of this new stress field is only a fraction of the extreme topography seen along the chain axis; examples of that are the western side of the Mt. Vettore-Mt. Bove range, the northern side of the Gran Sasso range, and the VelinoSirente, Majella and Matese massifs as a whole. In their turn most of the intervening basins do not show the architecture that would result from sustained extensional faulting. The Colfiorito Plain, the Castelluccio Plain, the Amatrice Basin, and the Mid-Aterno Valley, the main depressions that lie in front of the three normal faults being analyzed in this work (from north to south), are consistently too shallow, too narrow, and too short to be the long-term effect of the seismogenic faults that lie next to them; faults which should generate halfgraben architectures that are not seen. 
At first glance the three earthquakes do appear to have affected lowlands - where population and infrastructures naturally concentrate - lying next to fault-controlled ranges. Yet a closer inspection of the InSARdetected elevation changes reveals that:

(a) most of the regions undergoing coseismic subsidence are areas of high topography, not basins or depressions; and

(b) the strain field associated with these typical Apennines earthquakes induces significant but relatively localized subsidence $(15-30 \mathrm{~cm}$ for the earthquakes being considered here) and very mild uplift $(2-4 \mathrm{~cm})$ over a much broader region.

As for (a), it should be recalled that the observed topography reversal is the expected outcome - and in fact a proof - of the current extensional regime being rather youthful (see Valensise and Pantosti [2001] and references therein). As for (b) one should recall that Bagnaia et al. [1992] pointed out on a purely geological basis that the central Apennines are currently dominated by "gravity faults" that are disrupting and lowering the axial portions of the fold-andthrust belt.

Finally, all three InSAR models show that the causative faults of the three investigated earthquakes tend to create a basin-and-range architecture whose wavelength perpendicular to the chain is at least twice the spacing between existing basin-bounding faults. Notice that any intervening afterslip or post-seismic relaxation would increase this wavelength, not reduce it. All these observations strongly suggest that the current landscape is largely a fossil terrain that is being slowly dismantled by the erosion caused by the well documented regional-scale uplift of the entire chain, and reshaped by the action of newly incepted normal faults such as those responsible for the three earthquake sequences investigated here (e.g. Cavinato et al. [2002] and Santo et al. [2014]). Dealing with a fossil landscape implies also that several faults that punctuate it have ceased their activity and participate only passively to the ongoing deformation (see Bonini et al. [2014] for a thorough discussion on these circumstances). One of many such cases is that of the Pettino fault, near L'Aquila: seen by many as a major active fault, it turned out to be "floating" in the hanging wall of the fault that caused the 6 April 2009, L'Aquila earthquake [Bonini et al., 2014].

\section{RELATIONS WITH SURFACE STRUCTURES: FAULTS}

InSAR data provide crucial evidence on the role played by any surface fault occurring in the region hit by a significant earthquake. Recall that InSAR observations record static slip - not just dynamic slip - over an interval of a few days before and after the event, and hence are suitable also to document postseismic readjustments, if any.

Figs. 2A, 2B, 2C show that for the 1997, 2009 and 2016 earthquakes most - if not all interferometric fringes describing the subsidence associated with the mainshock are neatly closed in front of the presumed surface expression of the primary fault, implying that slip in the uppermost portion (up to $2-4 \mathrm{~km}$ depth) of the fault was much smaller than in its lower portions. In contrast, Fig. 2D shows the case of the 1995 Dinar (Turkey) earthquake ( $M, 6.1$ ), where dynamic slip was modeled up to a depth of $1.4 \mathrm{~km}$ and where a $30 \mathrm{~cm}$-high scarp was observed along the upward prolongation of the model fault: in this latter case the fringes are broken against the scarp, or not resolvable due to diffuse deformation, thus testifying that at least part of coseismic slip propagated all the way to the surface. This different behavior is illustrated in Figs. 2 E, $2 \mathrm{~F}$ and in Table 2. 


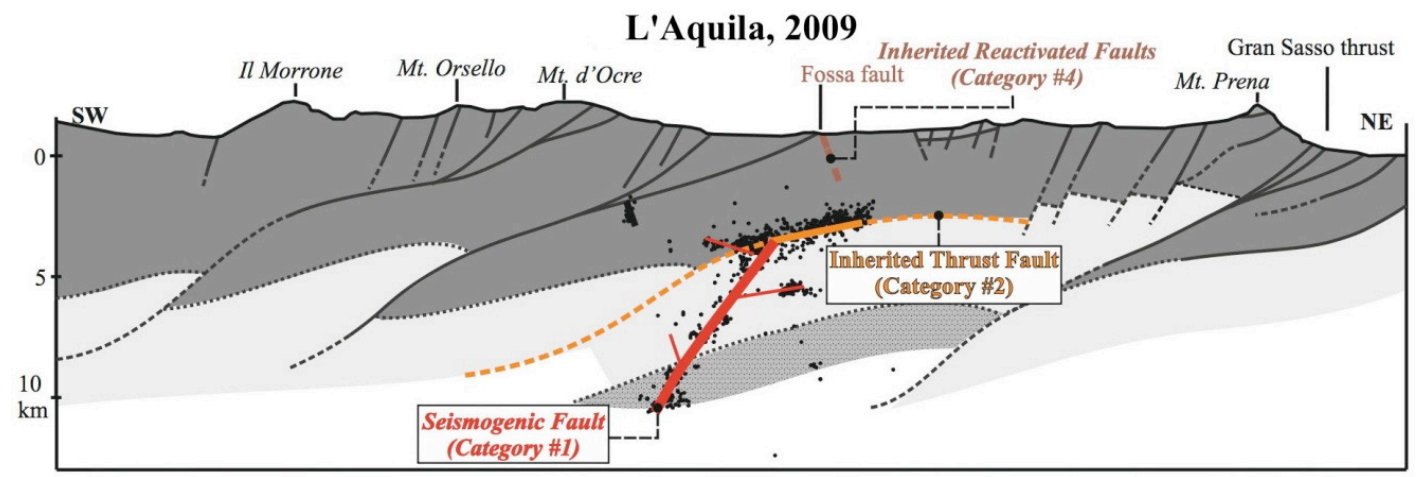

Colfiorito-Sellano, 1997
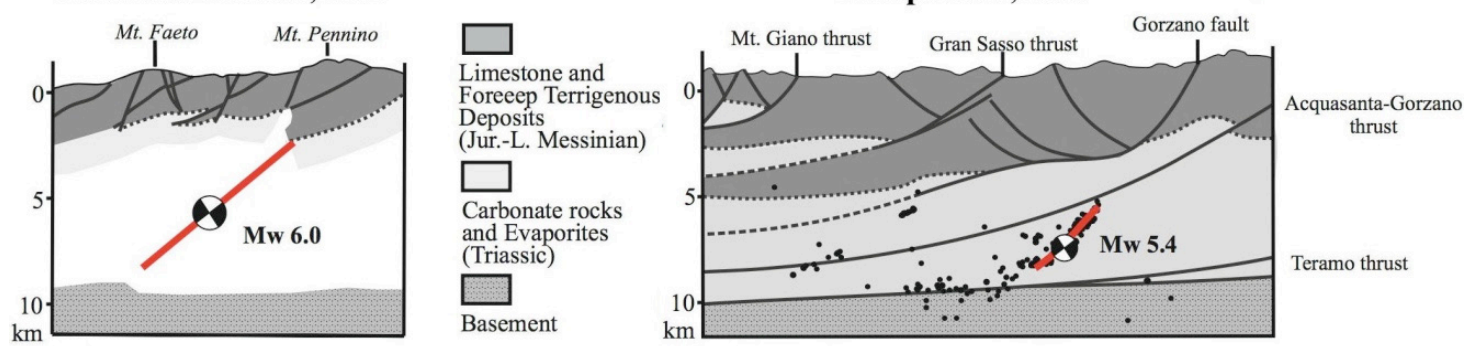

Figure 3. Geological sections across the causative faults of the 6 April 2009, L'Aquila, 26 September 1997, Colfiorito (based on data from Chiaraluce et al. [2005]), and 9 April 2009, Campotosto (based on data from Bigi et al. [2012]) earthquakes. The seismogenic sources are shown by a red line; black dots show aftershock locations. The sections illustrate the vertical confinement of the seismogenic sources within pre-existing thrusts, locally illuminated by minor aftershocks (from Bonini et al. [2014], modified).

\begin{tabular}{|c|c|c|c|c|c|c|c|c|c|c|c|c|c|}
\hline Source & $\begin{array}{c}\text { Strike } \\
\text { (deg) }\end{array}$ & $\begin{array}{c}\text { Dip } \\
\text { (deg) }\end{array}$ & $\begin{array}{l}\text { Rake } \\
\text { (deg) }\end{array}$ & $\begin{array}{l}\text { Length } \\
\text { (km) }\end{array}$ & $\begin{array}{l}\text { Width } \\
\text { (km) }\end{array}$ & $\begin{array}{l}\text { Top/bottom } \\
\text { depth (km) }\end{array}$ & $\begin{array}{c}\text { D1 } \\
\text { (km) }\end{array}$ & $\begin{array}{c}\mathrm{D} 2 \\
(\mathrm{~km})\end{array}$ & $\begin{array}{c}\text { D3 } \\
\text { (km) }\end{array}$ & $S_{\max }$ & $\mathrm{U}_{\max }$ & Rdisp & Rsym \\
\hline $\begin{array}{c}\text { Central } \\
\text { Apennines, Italy }\end{array}$ & 148 & 43 & 270 & 12.0 & 8.5 & $3.0-8.8$ & 4.7 & 9.5 & 8.3 & 0.370 & 0.025 & 14.8 & 2.0 \\
\hline Dinar, Turkey & 148 & 54 & 270 & 12.0 & 8.5 & $1.4-8.3$ & 2.6 & 12.4 & 4.6 & 0.450 & 0.075 & 6.0 & 4.8 \\
\hline
\end{tabular}

D1: Distance of maximum subsidence from intersection of fault prolongation with surface

D2: Distance of max subsidence from zero displacement line in hanging wall

D3: Distance of site of max subsidence from site of max uplift

\begin{tabular}{ll}
\hline Smax: Max subsidence (for unitary slip) & Umax: Max uplift (for unitary slip) \\
\hline Rdisp: $S_{\max } / U_{\max }$ & Rsym: D2/D1 \\
\hline
\end{tabular}

Table 2. Parameters used for the comparison of the "coseismic signatures" shown in Fig. 2 E-F. (see also Table 1).

The 24 August 2016 earthquake generated a $20 \mathrm{~cm}$-high scarp that could be followed over a distance of nearly $5 \mathrm{~km}$ along the Vettore Fault, a highly visible and highly recognized element in the central Apennines landscape [EMERGEO Working Group, 2016]. In the first few days after the earthquake many workers argued that this scarp is evidence for primary slip at seismogenic depth; others contended that the scarp is merely a surface effect unrelated to slip at depth. Crucial observations to settle this issue include:

1) seismological and geodetic evidence show that, largely due to its shallow dip, the plane that ruptured in the 24 August mainshock projects to the surface over $5 \mathrm{~km}$ ENE of the surface expression of the Vettore fault (see Fig. 2 in Michele et al. [2016] and Fig. 2 in Bonini et al. [2016]: see also our Figs. 2C, 2E); 
2) the elaboration of all of the three available InSAR datasets by different and independent groups (the Japanese ALOS-2, Sentinel-1 by the European Copernicus Program, and the Italian COSMO-SkyMed, developed by Agenzia Spaziale Italiana) and the slip model obtained by Tinti et al. [2016] from the inversion of strong motion records clearly shows that neither dynamic nor static slip occurred during the mainshock or in the following few days in the uppermost $3 \mathrm{~km}$ of the crust;

3) the Vettore Fault lies at the very northern end of the 2016 rupture: no sizable breaks have been observed along the central part of the rupture, for example along the wellknown Gorzano Fault. The observed 5 kmlong scarp is in an awkward position relative to the length of the earthquake source and is too short for a $\mathrm{M}_{\mathrm{w}} 6.0$ quake.

4) the Vettore Fault lacks a basin/depocenter representative of its long-term activity, knowing that the Castelluccio Plain is a karst basin elongated almost perpendicular to the Mt. Vettore ridge and filled with a thin veneer of continental deposits;

5) the surface breaks seen along the Vettore fault have been shown to be largely the result of landsliding and sediment compaction [Gruppo di Lavoro IREA \& INGV, 2016], as testified also by the recent geomorphological evolution of the portion of the Castelluccio Plain that lies at the base of the Vettore Mt. [Aringoli et al., 2014, and references therein].

For these reasons we maintain that the surface breaks seen along the western flank of the Vettore Mt. do not represent the primary expression of fault slip at depth, but rather some form of shaking-induced sliding along the Vettore Fault. This case is not isolated. In a large report written following the 13 January 1915, Avezzano-Fucino basin (central Apennines) earthquake $\left(\mathrm{M}_{\mathrm{w}} 7.0\right)$, Oddone [1915] described a large landslide affecting the talus deposits lying over the large and well known Serrone Fault. He described the landslide as clearly separated from the shaking. All buildings of the village of Gioia dei Marsi, unwisely built on these deposits, were totally destroyed, and every single wall was reported overturned. This suggests that their foundations had become loose under the combined action of shaking and gravity sliding. Similarly to the Vettore Fault, the Serrone Fault lies at the very end of the 1915 rupture, to the southwest of the Fucino basin.

The literature of the central Apennines reports a number of faults that are considered both active and seismogenic. Vannoli et al. [2012], however, pointed out that these faults are too many, generally too small and too closely spaced to root in at seismogenic depth all at once. What is the evidence that they indeed play an active role in the current evolution of the region? Key observations include:

1) most, if not all, of the bedrock normal faults are closely associated with thrusts that were active between the Late Miocene and the Pliocene: if we admit that the onset of the current extensional regime is not older than the Early Pleistocene, these older normal faults may well be prone to be (passively?) reactivated, but they can hardly be seen as the primary expression of the current stress field;

2) the consistent lack of slip in the uppermost $3 \mathrm{~km}$ of the crust - either coseismic or slow/post-seismic - testified by InSAR data (Fig. 2) and consistent with the spatial distribution of aftershocks [Michele et al., 2016], indicates that the currently active seismogenic faults act independently from the structure and evolution of the shallowest portion of the crust;

3) basic knowledge on the structure of the Apennines fold-and-thrust belt aided by analogue models (see Bonini et al. [2015]) shows a sort of "vertical segmentation" of large active normal faults; these develop and 
grow in-between major pre-existing subhorizontal discontinuities - e.g. large thrust planes - that effectively isolate them from the surface;

4) InSAR evidence combined with the results of analogue modeling suggests that such discontinuities do not prevent the upward propagation of coseismic strain, but also that they do act as effective barriers for fault propagation, thus contributing to decouple the deeper from the shallower faults.

\section{CONCLUSIONS AND SHA IMPLICATIONS}

We have provided and discussed evidence showing that, similarly to the 1997 Colfiorito, and 2009 L'Aquila earthquakes, the 24 August 2016 Amatrice earthquake has been generated by a shallow-dipping, blind fault. As such this fault bears no relationships with the presumed active faults mapped in the region over the past 40 years. While this paper was under revision two additional damaging earthquakes occurred on 26 October near Visso-Ussita $\left(M_{w} 5.9\right)$ and on 30 October near Norcia $\left(\mathrm{M}_{\mathrm{w}}\right.$ 6.5). Preliminary analyses of these two events suggest that they were also generated by shallow-dipping faults, relatively deep faults, although the 30 October event appears to have caused a complex pattern of brittle surface deformation.

Once again the central Apennines seismogenic sources demonstrated to be youthful faults lying beneath a mattress formed by older thrusts and their accompanying extensional faults. The investigation of such deeper faults requires a new paradigm that finally acknowledges these circumstances and develops new and appropriate investigation strategies.

Our findings have four main categories of implications that need to be carefully considered to avoid gross misrepresentations of the local earthquake potential: a) the complex structure of the central Apennines fold-and-thrust belt causes the effective decoupling between the normal faults that affect the uppermost 2-4 $\mathrm{km}$ of the crust and current extension accommodated by larger faults lying beneath them. As a result, surface faults are crucial for land planning but carry little information on seismogenic processes at depth (see \#4 in previous section);

b) for the same reasons, the evolution of large-scale, long-term landscape features e.g. the evolution of basin architectures and the distribution of fluvial or marine terraces should be regarded as the main and most faithful indicators of ongoing long-term strain at depth;

c) as the current geodynamic and geomorphic evolution of the Apennines is controlled more by regional uplift than by localized faulting, and in consideration of the above \#a), one has to be extra careful not to interpret the largely climate- and gravitycontrolled evolution of steep Apennines mountain slopes as evidence for continuing activity of surface faults (an ample discussion on this topic is supplied in Kastelic et al. [2016]);

d) for exactly the same reasons, and based on the recent evidence from the Vettore Fault, from the Serrone Fault in the Fucino basin and from a number of large landslides controlled by older surface faults (see Moro et al. [2007] and Moro et al. [2011], respectively for the 1997 and 2009 earthquakes), extreme care should be taken when trenching scarps of unproven origin; since they may represent only the accumulation of deposits mobilized by shaking, they may carry information suitable for dating the shaking itself but not for deriving meaningful slip rates or $\mathrm{M}_{\mathrm{w}}$ estimates. 


\section{ACKNOWLEDGEMENTS}

We wish to thank an anonymous reviewer for a thoughtful revision. The work was supported by the Project "Abruzzo" (code: RBAP10ZC8K_001; RBAP10ZC8K_003), funded by the Italian Ministry for Education, University and Research (MIUR), and by the University of Trieste, program "Finanziamenti di Ateneo per progetti scientifici - FRA 2015”, P.I. Lorenzo Bonini.

\section{REFERENCES}

Aringoli, D., and 17 others (2014). Morphotectonic characterization of the quaternary intermontane basins of the Umbria-Marche Apennines (Italy). Rend. Fis. Acc. Lincei, 25, 111-128, doi: 10.1007/s12210014-0330-0.

Bagnaia, R., A. D'Epifanio and S. Sylos Labini (1992). Aquila and Subequan basins: An example of Quaternary evolution in central Apennines, Italy, Quat. Nova, 2, 187209.

Basili, R., V. Bosi, F. Galadini, P. Galli, M. Meghraoui, P. Messina, M. Moro and A. Sposato (1998). The Colfiorito earthquake sequence of September-October 1997: surface breaks and seismotectonic implications for the Central Apennines, J. Earthq. Eng. 2, 291-302.

Basili, R., and M. M. Tiberti (2016). New statistics of earthquake-fault dip angles. Paper ESC2016-447, presented at the 35th General Assembly of the European Seismological Commission, Trieste, 4-10 September 2016.

Bigi, S., P. Casero, C. Chiarabba and D. Di Bucci (2012). Contrasting surface active faults and deep seismogenic sources unveiled by the 2009 L'Aquila earthquake sequence (Italy), Terra Nova, 25, 1, 21-29, doi: $10.1111 /$ ter. 12000 .

Bonini, L., D. Di Bucci, G. Toscani, S. Seno and G. Valensise (2014). On the complexity of surface ruptures during normal faulting earthquakes: excerpts from the 6 April 2009 L'Aquila (central Italy) earthquake (Mw 6.3), Solid Earth, 5, 389-408, doi: 10.5194/ se-5-389-2014.

Bonini, L., R. Basili, G. Toscani, P. Burrato, S. Seno and G. Valensise (2015). The role of pre-existing discontinuities in the development of extensional faults: an analog modeling perspective, J. Struct. Geol. 74, 145-158. doi: 10.1016/j.jsg.2015.03.004.

Bonini, L., F. E. Maesano, R. Basili, P. Burrato, M.M.C. Carafa, U. Fracassi, V. Kastelic, G. Tarabusi, M.M.Tiberti, P. Vannoli and G. Valensise (2016). Imaging the tectonic framework of the 2016 Amatrice earthquake: new roles for old players? Annals of Geophysics, 59 (5), doi: 10.4401 / ag-7229.

Cavinato, G. P., C. Carusi, M. Dall'Asta, E. Miccadei and T. Piacentini (2002). Sedimentary and tectonic evolution of PlioPleistocene alluvial and lacustrine deposits of the Fucino Basin (central Italy). Sedimentary Geology 148:29-59 doi: 10.1016/S0037-0738(01)00209-3.

Chiaraluce, L., M. R. Barchi, C. Collettini, F. Mirabella and S. Pucci (2005). Connecting seismically active normal faults with Quaternary geological structures in a complex extensional environment: the Colfiorito 1997 case history (Northern Apennines, Italy), Tectonics 24, TC1002. doi:10.1029 / 2004 TC001627.

Cinti, F. R., L. Cucci, F. Marra and P. Montone (2000). Surface tectonic effects vs seismological data of 1997 Umbria-Marche earthquakes (Italy), J. Seismol., 4, 333-343.

DISS Working Group (2015). Database of Individual Seismogenic Sources (DISS), Version 3.2.0: A compilation of potential sources for earthquakes larger than M 5.5 in Italy and surrounding areas. http:/ / diss.rm.ingv.it/diss/ (C) Istituto Nazionale di Geofisica e Vulcanologia, doi: 10.6092 / INGV.IT-DISS3.2.0. 
ANNALS OF GEOPHYSICS, 59, Fast Track 5, 2016; DOI: 10.4401/ag-7215

Douglas, B., and G. Funning (2016). Imaging active tectonics with InSAR and LiDAR. GETSI's Earth-focused Modules and Courses for the Undergraduate Classroom, http: / / serc.carleton.edu/124395.

EMERGEO Working Group: Pucci, S., and 46 others (2016). Coseismic effects of the 2016 Amatrice seismic sequence: first geological results. Annals of Geophysics, 59, Fast Track, 5, doi: 10.4401/ag-7195.

ESA (2009). An Envisat Advanced Synthetic Aperture Radar interferogram interpretation by INGV: http://www.esa. int/spaceinimages/Images/2009/04L_Aquil a_earthquake_Envisat_interferogram.

Gruppo di lavoro IREA \& INGV (2016). Sequenza sismica di Amatrice: aggiornamento delle analisi interferometriche satellitari e modelli di sorgente. doi: 10.5281 / zenodo.61682.

Kastelic, V., P. Burrato, M. M. C. Carafa and R. Basili (2016). Repeated surveys reveal non-tectonic exposure of supposedly active normal faults in the central Apennines, Italy. Submitted to J. Geophys. Res.

Michele, M., R. Di Stefano, L. Chiaraluce, M. Cattaneo, P. De Gori, G. Monachesi, D. Latorre, S. Marzorati, L. Valoroso, C. Ladina, C. Chiarabba, V. Lauciani and M. Fares (2016). The Amatrice 2016 seismic sequence: a preliminary look at the mainshock and aftershocks distribution, Annals of Geophysics, 59 (5), doi: 10.4401 / ag-7227.

Moro, M., M. Saroli, S. Salvi, S. Stramondo and F. Doumaz (2007). The relationship between seismic deformation and deep-seated gravitational movements during the 1997 Umbria-Marche (Central Italy) earthquakes, Geomorphology, 89, 297307, doi:10.1016/j.geomorph.2006.12.013.

Moro, M., M. Chini, M. Saroli, S. Atzori, S. Stramondo and S. Salvi (2011). Analysis of large, seismically induced, gravitational deformations imaged by high-resolution COSMO-SkyMed synthetic aperture radar,
Geology, 39(6), 527-530， doi:10.1130/ G31748.1.

Oddone, E. (1915). Elementi fisici del grande terremoto Marsicano-Fucense del 13 gennaio 1915, Boll. Soc. Sismologica Italiana, 19, 71-217.

Pucci, S., F. Mirabella, F. Pazzaglia, M. R. Barchi, L. Melelli, P. Tuccimei, M. Soligo and L. Saccucci (2014). Interaction between regional and local tectonic forcing along a complex Quaternary extensional basin: Upper Tiber Valley, Northern Apennines, Italy, Quat. Sci. Rev., 102, 111-132, doi: 10.1016/j.quascirev.2014.08.009.

Santo A., A. Ascione, G. Di Crescenzo G., E. Miccadei, T. Piacentini and E. Valente (2014). Tectonic-geomorphological map of the middle Aterno River valley (Abruzzo, Central Italy), Journal of Maps, 10 (3), 365378, doi: 10.1080/17445647.2013.867545.

Tinti, E., L. Scognamiglio, A. Michelini and M. Cocco (2016). Slip heterogeneity and directivity of the ML 6.0, 2016, Amatrice earthquake estimated with rapid finite-fault inversion, Geophys. Res. Lett., doi: 10.1002 / 2016GL071263.

Valensise, G., and D. Pantosti (2001). The investigation of potential earthquake sources in peninsular Italy: a review, J. of Seismology, 5, 287-306.

Vannoli, P., P. Burrato, U. Fracassi and G. Valensise (2012). A fresh look at the seismotectonics of the Abruzzi (Central Apennines) following the 6 April 2009 L'Aquila earthquake (Mw 6.3), Ital. J. Geosci., 131, 309-329, doi: 10.3301 / IJG.2012.03.

Wright, T. J., B. E. Parsons, J. A. Jackson, M. Haynes, E. J. Fielding, P. C. England and P. J. Clarke (1999). Source parameters of the 1 October 1995 Dinar (Turkey) earthquake from SAR interferometry and seismic bodywave modelling, Earth and Planetary Science Letters, 172, 23-37, doi: 10.1016/S0012-821X(99)00186-7. 